Howard Barnes, Louis King, Norman Shaw, John Stuart Foster, David Keys, Anna McPherson, Stuart Marshall, Walter Hitschfeld and Robert Bell, each of whom merits an article to himself or herself. And that excludes all the physicists who are still alive and working in the Department.

It must not be forgotten that the Macdonald Physics Building was designed not only for research but for teaching, too. Indeed, in an early article in Nature on "Physics and Engineering at the McGill University, Montreal" (October 4, 1894), the Physics Building is described as "designed for the teaching and study of physics (including mechanics) with special regard to (1) its intrinsic importance as an integral part of a liberal education in the Faculty of Arts; (2) its essential necessity as a study preliminary to the courses of engineering, mining, and practical chemistry in the Faculty of Applied Science, (3) prosecution of scientific research." It will be noted that the principal aims did not include the education and training of professional physicists! That came later, as Rutherford and others demonstrated the potential of Montreal as a world centre of science.

The Macdonald Physics Building served its original purpose, as a home for the teaching and development of science, until well past the Second World War — far beyond the original 50 years suggested by Eve—but, inevitably, it became too small and too inconvenient to satisfy the needs of modern physics. In 1977 the Physics Department moved into a new building on the upper campus, appropriately named the Rutherford Physics Building. The old Macdonald Building was then gutted, remodelled (at least, internally) and converted into a library. The Physical Sciences and Engineering Library was officially opened on May 19, 1982. Thus William Macdonald's original bequest, for the service of science and engineering, lives on in another guise. Long may it continue!

\title{
Views of Rome, Visions of Rome Piranesi Prints from the Nobbs Collection in the Blackader-Lauterman Library, McGill University
}

\author{
By Ron Harvie \\ Ph.D. candidate, Department of Art History
}

Giovanni Battista Piranesi (1720-1778) was one of the great masters, along with Rembrandt and Goya, of the highly demanding medium of etching. He was also that rarity, an artist who was able to combine commerce and conviction. For while he successfully supplied the ever-increasing demand by tourists for inexpensive souvenirs of Rome, Piranesi never abandoned his own personal vision of what the city stood for.

Briefly stated, Piranesi's concept was that the seeds of classic art had origniated in Italy, germinated in Greece and flowered most perfectly again in Rome.' The more that archaeological discoveries refuted him, the more steadfastly, and profusely, Piranesi maintained his position. This wrong-headed obsession led Horrace Walpole to write of "the sublime dreams of Piranesi, who seems to have conceived visions of Rome beyond what it boasted even in the meridian of its splendour." ${ }^{2}$ Piranesi's images, however, clearly matched the romantic, neoclassic sensibility then so prevalent, particularly in northern Europe.

Although his name is forever attached to Rome, Piranesi was actually Venetian. He was born, and had his early training (as an architect and a theatrical set decorator) in Venice, and the romantic spirit of this city seems to infuse his etcher's needle. So does the Venetian sense of drama, which bad been sharpened by study with Bibiena, the self-styled inventor of the scena per angolo, (the use of exaggerated low-angle diagonal perspective in stage scenery). Thus, Piranesi's work melds two traditions which appear mutually exclusive: that of the Baroque theatre with that of topographically accurate renderings of architecture. ${ }^{3}$ 


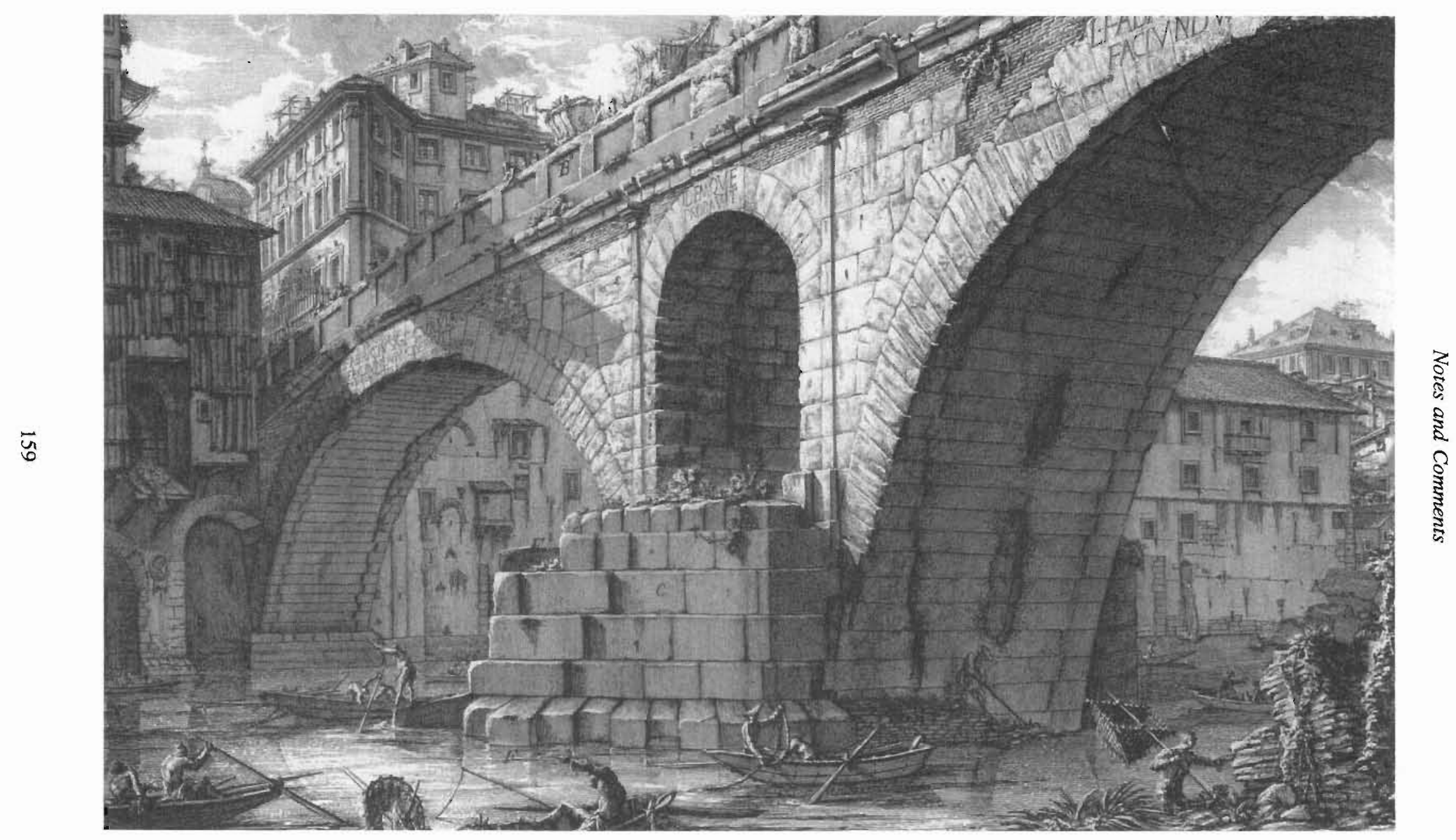

View of Ponte Fabrizio, ca. 1762. 
Piranesi was also a very productive artist. During his career, he made over 1000 etchings, most of them large and densely detailed. Moreover, he claimed that he had to take 4000 impressions-far beyond the normal numberfrom every single plate in order to make a living! For this reason, he was careful to develop a technique based on parallel etched lines, rather than cross-hatching, so that the images pulled from his plates would remain crisper and clearer over large numbers of impressions. It is this volume of prints, often with only minor revision, taken over a long period of time which has made dating Piranesi's work so tricky. ${ }^{4}$

Piranesi first went to Rome in 1740, where he studied etching and met the important cityscape-painter Pannini. 1743 saw the publication of his first mature work, the Prima Parte di Architetture e Prospettive, done in a rather stiff, formal style and not a major success. He returned to Venice that year, where he is believed to have worked in Tiepolo's studio. In 1745, he returned to Rome as a print-publisher's agent and remained there the rest of his life. The first segment of his famous Vedute di Roma may have been published in 1748, although the first dated edition is from 1751. Piranesi continually expanded this work over the years until it comprised 135 plates.

Perhaps the best known of Piranesi's works, the Invenzioni Capric. di Carceri, or Imaginary Prisons, first appeared in 1749. These fourteen etchings of malevolent-looking architectural mazes have created today's image of Piranesi as a proto-Freudian artist of surrealistic, demonic dreamscapes (see Postscript below).

In 1756, Piranesi published the four-vlume Le Antichita Romane. This massive work, combining dramatic scenic views of Roman monuments along with exact architectural renderings of them, made Piranesi a celebrity throughout Europe and shows him clearly as both a great artist and a dedicated archaeologist.

Throughout his life, Piranesi continued to publish all his works extensively, in various permutations and combinations, with continual additions and revisions. He also created a vast series of single plates of architectural ornaments and details, which has been invaluable to scholars of the antique style ever since. Piranesi died in 1778, and his sons Francesco and Pietro continued the publication of his work. In fact, Francesco etched additional plates in the manner of his father, adding yet another difficulty to the cataloguing of Piranesi's work. In 1798, the brothers took all Piranesi's plates to Paris, where they were published until 1839. Then they were bought by the Camera Apostolica and returned to Rome.

The etchings owned by McGill were collected by the well-known Montreal architect, Percy E. Nobbs, and presented to the Blackader-Lauterman Library by his son after Mr. Nobb's death in 1964. It is interesting to note that the collector's own fascination with the structure of bridges is reflected in the group of prints: four of the seven are bridge scenes.

1. Frontispiece with Statue of Minerva, ca. 1748.

$49 \times 63 \mathrm{~cm}$.

Third State

F. $786 ;$ H. $2^{5}$

From Piranesi's Vedute di Roma, this served as the frontispiece to Volume II in posthumous editions. It is an example of a capriccio, a collection of ancient buildings and/or sculpture arranged arbitrarily to make a dramatic image: nowhere like this actually existed, although elements in it are recognizable, e.g. the Hercules Farnese, a Roman marble copy of the 4th century B.C. bronze attributed to Lysippos, can be seen in the upper left corner.

Judging by the address in the lower left margin, this impression dates from between 1761, when Piranesi established his studio in Palazzo Tomati, and 1778, the year of his death. 


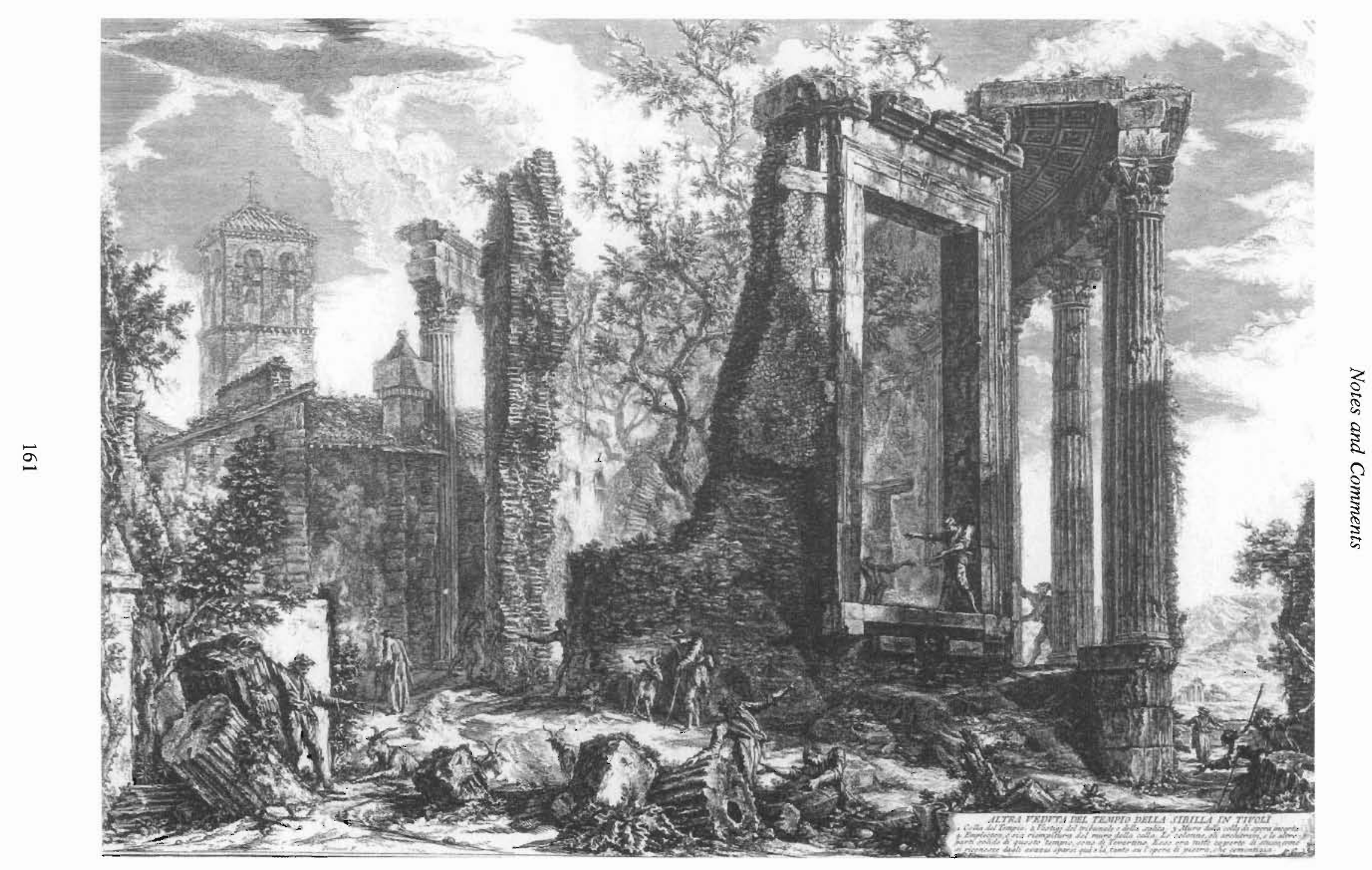

View of the Temple of Sibyl, Tivoli, ca. 1780. 
2. View of a Cistern at Castel Gandolfo, ca. 1764.

$40 \times 61 \mathrm{~cm}$.

F. 531

This is Plate 22 from Piranesi's Antichita d'Albano e di Castel Gandolfo, published in 1764. The summer residence of the Popes since Urban VIII (1623-44), Castel Gandolfo is on the edge of Lake Albano, south of Rome. In ancient times, the area was a reservoir for the city, and this etching shows the ruins of a watercollecting cistern. Stylistically, it is very reminiscent of the dark, disturbing series, Imaginary Prisons, perhaps Piranesi's most famous work.

This particular impression was printed after 1870 .

3. View of Ponte Fabrizio, ca. 1756.

$36 \times 60 \mathrm{~cm}$.

F. 531 .

From Le Antichita Romane, the four-volume work which made Piranesi famous in artistic and antiquarian circles throughout Europe, this shows the best preserved of the ancient bridges of Rome. Built by the consul L. Fabricius in 62 B.C., the bridge links the east bank of Rome to the Isola Tiberina. It is now known as the Ponte dei Quattro Capi. The wonderful detailing shows why Piranesi was, and is, so highly regarded among architects and archaeologists.

This print was taken after 1870 .

4. View of the Temple of the Sibyl, Tivoli, ca. 1780.

$47 \times 65 \mathrm{~cm}$.

This etching is by Francesco Piranesi, the artist's son, and was part of Raccolta de' Tempi Antichi, which he published two years after his father's death. The composition is based on one of the most evocative plates in the Vedute di Roma (F. 766; H. 63), but Francesco took only half the image created by Piranesi, changed the angle of viewing slightly and added statuary and other figures.

Tivoli, twenty miles northeast of Rome, was a favorite resort of well-to-do Romans and reached the zenith of its splendor under Emperor Hadrian (117-38 A.D.). This temple dates from the first century B.C. and to this day its true identity remains unknown: it is sometimes called the Temple of Vesta.

The print dates from after 1870 .

5. View of the Ponte d'Elio Adriano, ca. 1756.

$37 \times 60 \mathrm{~cm}$.

F. 347

Another plate from Le Antichita Romane, this image shows the ancient Pons Aelius, built by the Emperor Hadrian in 134 to provide easy access to his massive tomb, now known as the Castel Sant'Angelo and one of Rome's major sights, on the right bank of the Tiber. This bridge is now best known for the statues of angels bearing the instruments of Christ's Passion, commissioned from Bernini in the 17th century (the actual statues were carved by Bernini's assistants).

This impression was printed after 1870 . 
6. View of the Isola Tiberina, ca. 1775.

$47 \times 71 \mathrm{~cm}$.

Third State

F. 836 ; H. 121

Legend says that the island in the Tiber acquired its religious significance in 292 B.C., when a snake brought to Rome from the Temple of Asklepios at Epidauros in Greece escaped and swam out to it. A temple to the god of medicine, the Roman Aesculapius, was immediately built there. In the print, a plate from the Vedute di Roma, remains of the ancient embankment are clearly visible and a statue (Piranesi's invention) of the god with the snake on his staff is seen at letter B.

Judging by two sets of numbers in the upper right corner, this impression dates from 1830-39.

7. View of the Ponte Molle, ca. 1762.

$43 \times 66 \mathrm{~cm}$.

First State

F.f $767 ;$ H. 64

Another plate from the Vedute di Roma, this shows the Milvian Birdge, which takes the Via Flaminia across the Tiber north of Rome. Originally in the countryside, the spot is now near Rome's Olympic Stadium and completely urbanized. The bridge is best known as the site of the battle between Constantine and Maxentius in 312 A.D., at which the Emperor, inspired by a vision of the Cross, converted to Cristianity and was victorius.

Again, the fine detail of the etching underscores Piranesi's knowledge of the architectural methods of the ancients as well as his abilty to enliven what might have been a dry archaeological subject.

This particular impression (which shows some damage in the lower left corner) was probably made during Piranesi's llifetime, i.e. before 1778.

\section{$* * * * * *$ \\ Postscript}

There is a copy of Piranesi's Opera Varie di architettura, prospettiva, grotechi, antichita in the Department of Rare Books and Special Collections. It was published in Rome by Giovanni Bouchard in 1760-61. It was through the efforts of Ramsey Traquair, Director of McGill's School of Architecture from 1913-1939, that the McGill libraries was able to acquire this important work. The McGill copy of the Opera Varie, bound in an 18th-century English binding, includes a complete set of the 14 prints of the first edition of Piranesi's Carceri series. (The Rare Book Department's Print Collection houses a complete set of the dramatically reworked fourth edition of the Carceri.) Among other important prints in the volume are a complete 2nd edition set of the Prima Parte, the thirty plates of the Antichita Romane de Tempi della Reppublica, four Grotteschi, and the title-page and 8 plates from the Trofei.

\section{Notes}

1. A. Hyatt Mayor, Giovanni Battista Piranesi (New York, 1952) 3.

2. Peter Murray, Piranesi and the Grandeur of Ancient Rome (London, 1971) 58. 
4. Andrew Robinson, "Dating Piranesi's Early 'Vedute di Roma'" Piranesi tra Venezia e l'Europe (Venice, 1983) $11 \mathrm{ff}$.

5. The "F-" and "H-" numbers refer to the two standard catalogues raisonnés of Piranesi's work, Henri Focillon, Giovanni-Battista Piranesi, essai de catalogue raisonné de son oeuvre, (1918): and Arthur M. Hind, Giovanni Battista Piranesi: A Critical Study, (1922).

\title{
"House Portraits" Four Krieghoff Oil Paintings at the McCord Collection
}

\author{
By Conrad E.W. Graham \\ Curator of Decorative Arts, McCord Museum of Canadian History
}

The McCord Museum of Canadian History acquired in 1990, as the gift of Mr. And Mrs. David M. Campbell, four "house portraits" by Cornelius Krieghoff. "House portraits" while popular and not unusual in Britain and the United States, are much less common in Canada and were commissioned only by the most well established citizens. These four Krieghoff paintings are an important addition to the McCord Museum's collection of historical paintings.

Cornelius Krieghoff was born in Amsterdam in 1815, the son of Ernest Krieghoff a wallpaper manufacturer of Düsseldorf, Germany and a Flemish mother. Brought up in Bavaria he is said to have studied painting in Düsseldorf ${ }^{1}$ and have travelled Europe as an itinerant musician and painter. In 1837 he emigrated to the United States and enlisted as an artificer in the American army. He made drawings for the army during the Seminole War in Florida. ${ }^{2}$ Discharged from the army in Burlington, Vermont in 1840, he married Emily Saintaguta of Boucherville, Quebec shortly thereafter, although no marriage certificate has been located. By 1841 the Krieghoff family was living in Montreal but in the middle of the year moved to Rochester, New York probably because he could not obtain enough work as an artist. By 1845 they had returned and had taken up residence in Longueuil. Krieghoff worked in the Montreal area until 1853 when he moved to Quebec where he remained until 1863 and to which he returned in 1869-1871. He died in Chicago in $1872 .{ }^{3}$ Krieghoff was trained in the German genre painting tradition, and the secular subject matter had a sense of immediacy that Canadian customers came to prefer over the more formal neo-classical subjects that had preceded Krieghoff in Canada.

The four "house portraits" painted by Cornelius Krieghoff in 1846, and now part of the McCord collection, were commissioned by the Hon. Edward Hale (1800-1875). They represent one of the earliest commissions that Krieghoff received upon setting up his studio in Montreal. In a letter from Fanny Hale to her brother Edward she makes reference to the fact that she is sending him sketches of the old house and how wonderful it will be to have them in colour, ${ }^{4}$ this probably refers to the sketchbook of her mother Elizabeth Hale now in the National Archives, Ottawa. ${ }^{5}$ This sketchbook includes six sketches of the manor at Ste-Anne-de-la-Pérade and were probably used by Krieghoff in preparing his composition. The two ancestral houses were most probably painted from engravings. Krieghoff would have considered this commission to be a very important one as it was this type of clientele which he both wished and needed to cultivate in order to survive in Canada. Likewise, when displayed in the Hale house, the paintings displayed their old and new world roots and that they were part of the "establishment".

The Hon. Edward Hale (1800-1875) was a businessman of some standing, a member of the House of Assembly for Sherbrooke and a Legislative Councillor. ${ }^{6}$ He purchased 600 acres on the banks of the St. Francis river in late 1833 or early 1834 and probably built the house "Sleepy Hollow" during 1834. The museum has portraits of both Edward and his wife signed and dated by Alonzo Slafter 1834, and Slafter is known to have been accepting commissions in Sherbrooke during this year. 